\title{
Gnotobiotic system for selecting microorganisms with biocontrol potential against Fusarium oxysporum f. sp. physali
}

\section{Sistema gnotobiótico para seleccionar microorganismos con potencial de biocontrol contra Fusarium oxysporum f. sp. physali}
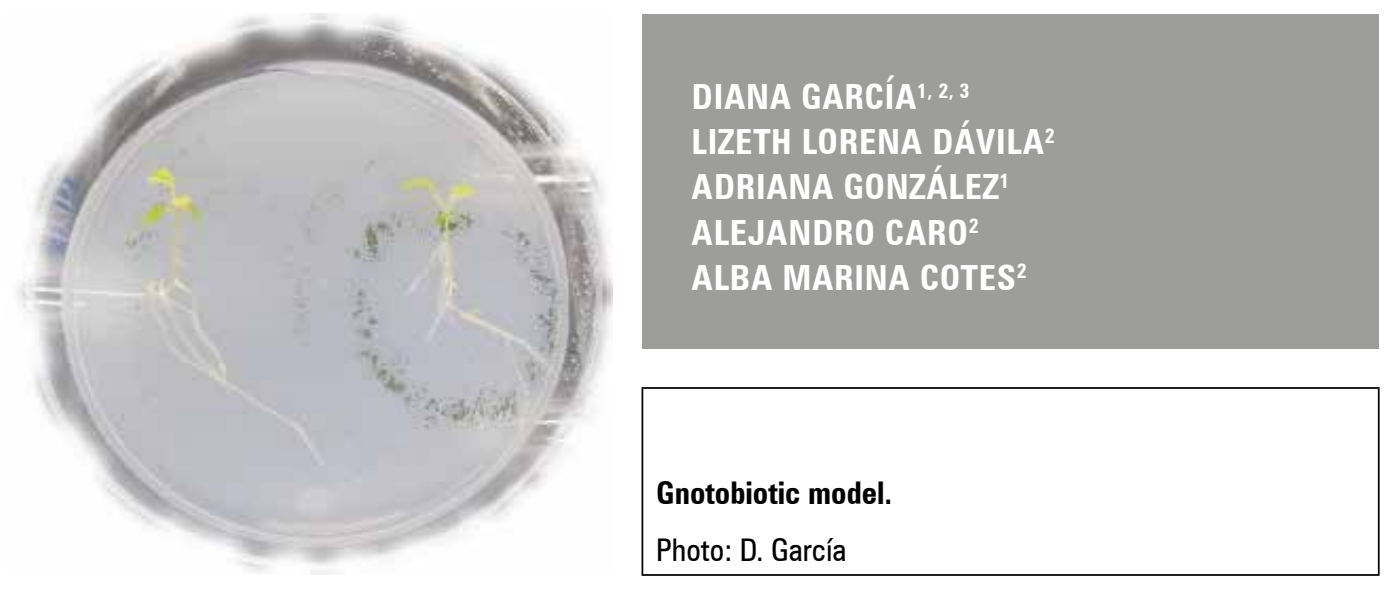

\begin{abstract}
The cape gooseberry (Physalis peruviana) is a Solanaceae species with enormous economic importance in Colombia; it is the second most exported fruit, after bananas. Vascular wilt caused by Fusarium oxysporum $\mathrm{f}$. sp. physali (Fox) is the most limiting factor of this crop, with losses of up to $80 \%$ of production. Biological control is a promising alternative for controlling this pathogen. Bacteria and fungi, originally isolated from potentially suppressive soils of cape gooseberry crops in Nariño, Colombia with different management (organic and conventional), were evaluated as biocontrol agents of Fox using a gnotobiotic model (seedlings cultured under axenic conditions with defined microbial strains). Of the 64 isolated microorganisms, $37.5 \%$ (15 bacteria and 9 fungi) were discarded because of toxicological risks and an unknow potential biological control. The remaining $62.5 \%$ of the microorganisms, 14 bacteria and 26 fungi, were evaluated to assess their potential as biological control agents against Fox. The gnotobiotic model system evaluated the protection and plant growth promotion characteristics. Response variables were used to group the microorganism using a principal component analysis (PCA), and five clusters were obtained. Cluster number four concentrated the 10 microorganisms (three bacteria and seven fungi) with the highest protection values against Fox, with a positive effect on growth. The isolates were identified as two Bacillus subtilis strains, Rhodococcus sp., Podospora setosa, Debaryomyces vindobonensis, Plectosphaerella plurivora, Acinetobacter rhizosphaerae, Umbelopsis sp. and two strains of Trichoderma koningiopsis. The gnobiotic system offered clear advantages for evaluating and selecting microorganisms with a biological control potential against Fusarium oxysporum f. sp. physalis.
\end{abstract}

1 Universidad Nacional de Colombia, Facultad de Ciencias Agrarias, Bogota (Colombia). ORCID García, D.: 0000-0002-7843-6950; ORCID González, A.: 0000-0003-2261-8912

2 Corporación Colombiana de Investigación Agropecuaria (AGROSAVIA), Centro de Investigación Tibaitatá, Mosquera (Colombia). ORCID Dávila, L.L.: 0000-0002-3516-481X; ORCID Caro, A.: 0000-0001-8807-671X; ORCID Cotes, A.M.: 0000-0003-3649-5706

3 Corresponding author. dgarciav5@gmail.com 


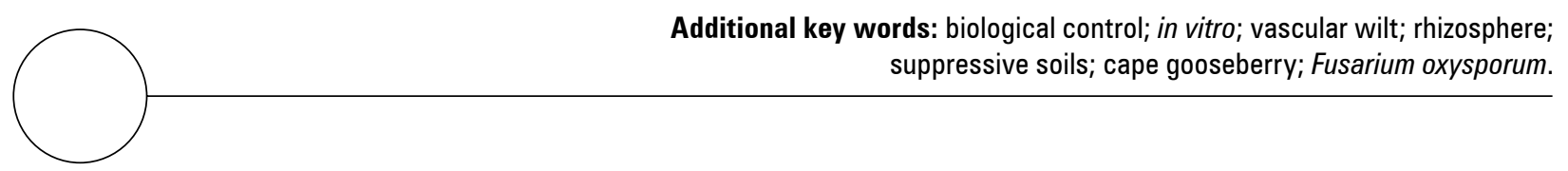

\section{RESUMEN}

La uchuva (Physalis peruviana) es Solanaceae de enorme importancia económica en Colombia ya que es la segunda fruta más exportada después del banano. La marchitez vascular causada por Fusarium oxysporum f. sp. physali (Fox) es el factor más limitante de este cultivo, que ocasiona pérdidas de hasta el $80 \%$ de su producción. El control biológico se ha convertido en una alternativa prometedora para controlar este patógeno. Bacterias y hongos, originalmente aislados de suelos potencialmente supresores de cultivos de uchuva de Nariño, Colombia con diferente manejo (orgánico y convencional) fueron evaluados como agentes de control de Fox utilizando un modelo gnotobiótico (plántulas cultivadas en condiciones axiológicas con cepas microbianas definidas). A partir de los 64 microorganismos aislados, $37.5 \%$ (15 bacterias y nueve hongos) fueron descartados debido a su riesgo toxicológico y a un control biológico potencial desconocido, el 62.5\% restante de microorganismos, 14 bacterias y 26 hongos, se evaluaron para evaluar su potencial como agentes de control biológico contra Fox. El sistema de modelos gnotobióticos nos permitió evaluar las características de protección y promoción del crecimiento vegetal, estas variables de respuesta se utilizaron para agrupar el microorganismo utilizando un análisis de componentes principales (PCA) y se obtuvieron cinco clústeres. El clúster número cuatro concentró 10 microorganismos (tres bacterias y siete hongos) con los valores de protección más altos contra Fox y con un efecto positivo en la promoción del crecimiento. Los aislados fueron identificados como dos cepas de Bacillus subtilis, Rhodococcus sp., Podospora setosa, Debaryomyces vindobonensis, Plectosphaerella plurivora, Acinetobacter rhizosphaerae, Umbelopsis sp. y dos cepas de Trichoderma koningiopsis. El sistema gnobiótico presentado ofrece claras ventajas para evaluar y seleccionar microorganismos con un potencial de control biológico contra Fusarium oxysporum f. sp. fisalis.

Palabras clave adicionales: control biológico; in vitro; marchitamiento vascular; rizósfera; suelos supresores; uchuva; Fusarium oxysporum.

Received: 06-09-2020 Accepted: 01-12-2020 Published: 15-01-2021

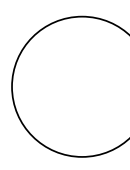

The cape gooseberry or golden berry (Physalis peruviana L.) is an herbaceous plant of the Solanaceae family (NRCS, 2020), with 1,311.8 ha planted in Colombia, mainly in the Boyaca, Cundinamarca and Nariño departments (Agronet, 2018), where it is grown commercially at altitudes between 1,800 and 2,800 $\mathrm{m}$ a.s.l., with medium temperatures between 13 and $16^{\circ} \mathrm{C}, 1,500-2,000 \mathrm{~h}_{\text {year }}{ }^{-1}$ of direct sunshine, and 1,000-1,800 mm year ${ }^{-1}$ of rainfall (Fischer and Melgarejo, 2020). Its fruit is a sugary berry preferred in countries such as Germany, Canada, Brazil, the Netherlands and Belgium, which are the main consumers (Hassanien et al., 2011). However, this crop is severely affected by vascular wilt, caused by Fusarium oxysporum, Schltdl., throughout Colombia (Galindo and Pardo, 2010; Enciso-Rodríguez et al., 2013;
Villareal-Navarrete et al., 2017; Rodríguez, 2013; Giraldo-Betancourt et al., 2020), generating losses of up to 100\% (Smith, 2012; Mayorga-Cubillos et al., 2019) and forcing the movement of crops to other producing areas (González and Barrero, 2011).

Controlling this fungus is difficult because of the presence of inoculum in the soil, crop residues, infected plant debris and contaminated soils (McGovern, 2015). Plants can be infected by mycelium, conidia and chlamydospores (dormant propagules), which germinate when they come into contact with plant root exudates (Haglund and Kraft, 2001; Michielse and Rep, 2009; Zacky and Ting, 2013). In Colombia, the principal management strategy for this disease is treatment with flutriafol, propineb, iprodione and 
chlorothalonil, among other chemicals (ICA, 2020). However, their efficacy is less than $30 \%$ (Bennett et al., 2011). Therefore, these methods for controlling this pathogen and cultural practices have not been enough (McGovern, 2015).

The use of antagonistic microorganisms for biological control is a promising alternative that has been incorporated into disease management (Köhl et al., 2019).

Studies on tomatoes and bananas under greenhouse conditions have shown that non-pathogenic strains of $F$ oxysporum reduce the severity of this disease (Shishido et al., 2005). A similar effect has been reported with the addition of the mycorrhizal fungus Glomus intraradices (Akköprü and Demir, 2005). Cape gooseberry crops have used strains of Pseudomonas fluorescens for biocontrols, decreasing the incidence of this disease in plants (Urrea et al., 2011; Toloza-Moreno et al., 2020). Additionally, the biocontrol agents (BCAs) Brevibacillus brevis and Trichoderma harzianum have reduced the severity of the disease caused by F. oxysporum f. sp. lycopersici and $F$. oxysporum f. sp. cubense in tomatoes and bananas by 30 and $55 \%$, respectively, and by $45 \%$ against $F$. oxysporum $\mathrm{f}$. sp. phaseoli when was applied to bean seeds at greenhouse conditions (Carvalho et al., 2014; Bubici et al., 2019).

Another interesting approach that has been studied around the world for the control of Fusarium sp. uses suppressive soils, where the microbial community in the soil controls this pathogen and reduces the incidence of the disease. Siegel-Hertz et al. (2018) reported that Adhaeribacter, Massilia, Microvirga, Rhizobium, Rhizobacter, Arthrobacter, Amycolatopsis, Rubrobacter, Paenibacillus, Stenotrophomonas and Geobacter generated suppressive soils against $F$. oxysporum f. sp. lini in Linum usitatissimum. Likewise, it has been suggested that microorganisms isolated from the rhizosphere of a specific pathosystem provide better control of this disease in the same crop since they are already adapted to the host, as opposed to introducing organisms from other pathosystems (Lucy et al., 2004). The use of microorganisms in consortia from potentially suppressive soils reduced this disease more efficiently than the use of individual agents in tomato and radish crops (Bubici et al., 2019). The microbiome of soils can limit the presence of phytopathogens, so this study focused on selecting microorganisms that have been isolated from the cape gooseberry rhizosphere of potentially suppressive soils with a biocontrol potential against $F$. oxysporum $\mathrm{f}$. sp. physali using a gnotobiotic system.

\section{MATERIALS AND METHODS}

\section{Biological material}

Commercial cape gooseberry (Physalis peruviana) Colombia ecotype seeds were used for the assays. The seedlings were disinfected by immersing them in $70 \%$ ethanol ( $2 \mathrm{~min}$ ) and 3\% sodium hypochlorite (20 min), followed by three washings with sterile distilled water. Afterwards, they were left to dry and germinate in a humid and dark chamber for $12 \mathrm{~d}$ at $25^{\circ} \mathrm{C}$. During this disinfection procedure, no seeds showed symptoms of pathogen development.

The F. oxysporum f. sp. physali Map5 (Fox) strain was selected because of its high virulence in cape gooseberries (Rodríguez, 2010). Three small disks $(0.5 \mathrm{~cm})$ were taken from Potato Dextrose Agar cultures (PDA) that were incubated at $25^{\circ} \mathrm{C}$ for $8 \mathrm{~d}$, inoculated in 300 $\mathrm{mL}$ of Potato Dextrose Broth (PDB), and grown at $25^{\circ} \mathrm{C}$ with constant agitation at $125 \mathrm{rpm}$ for $7 \mathrm{~d}$ to obtain the microconidia. Subsequently, they were filtered through sterile muslin, and the inoculum was adjusted to a final concentration of $5 \cdot 10^{5} \mathrm{UFC} / \mathrm{mL}$ using a Neubauer chamber.

\section{Evaluation of the biocontrol activity of the microorganisms}

The microorganisms used in this study were provided by the Microbial Culture Collection, maintained by Agrosavia. The isolates were originally obtained from rhizospheric soils from two cape gooseberry farms, one with organic management and the other with conventional management, located in the Gualmatan and Puerres municipalities, respectively, in the Department of Nariño (Colombia). These zones have a historical absence of Fusarium wilt and have been pointed out as possible sources for suppressive soils. The filamentous fungi were recovered in PDA (Potato Dextrose agar) at $25^{\circ} \mathrm{C}$, the bacteria were recovered with LB (Luria-Bertani) at $28^{\circ} \mathrm{C}$ for $24 \mathrm{~h}$, and yeast was recovered on YM (Yeast Malt agar) at $25^{\circ} \mathrm{C}$ for $72 \mathrm{~h}$.

The taxonomic identification of these isolates was done by sequencing with molecular marker genes. For the fungi and yeasts, DNA was extracted using a ZR Fungal/Bacterial DNA MiniPrep Kit ${ }^{\mathrm{TM}}$, and, for the bacteria, an Invitrogen ${ }^{\mathrm{TM}}$ PureLink ${ }^{\mathrm{TM}}$ Genomic DNA Mini Kit was used according to the manufacturer's 
instructions. Once the nucleic acids were obtained, the ITS region of the fungi and yeasts was amplified with a PCR using the primers R_ITS4_KY03 and ITS3_KY02 (Toju, 2012), and, for bacteria, the primers $515 \mathrm{~F}$ and $806 \mathrm{R}$ were used to amplify variable region V3-V4 of ribosomal gene 16S rRNA (Caporaso et al., 2011). Subsequently, the products of this PCR were purified using magnetic beads (AgencourtAMPure XP beads) and were amplified with a second PCR with different combinations of barcode type primers for each sample to obtain a code for each one with simultaneous sequencing with pyrosequencing using the Illumina MiSeq ${ }^{\circledR}$ system.

For the $16 \mathrm{~S}$ rRNA gene library preparation, the first PCR was performed in a final volume of $25 \mu \mathrm{L}$, containing $0.1 \mu \mathrm{L}$ of Taq Platinum (Invitrogen), $0.75 \mu \mathrm{L}$ of $\mathrm{MgSO}_{4} 50 \mathrm{mM}, 2.5 \mu \mathrm{L}$ of Buffer-Mg $10 \mathrm{X}, 0.5 \mu \mathrm{L}$ of dNTPs $10 \mathrm{mM}, 0.5 \mu \mathrm{L}(10 \mu \mathrm{M})$ of each forward and reverse primers with adaptor sequences, $2 \mu \mathrm{L}$ of DNA and $18.15 \mu \mathrm{L}$ of Ultrapure Distilled Water (Invitrogen). The PCR was performed in a T100 ${ }^{\mathrm{TM}}$ Thermal Cycler, BioRad, with the following conditions: initial denaturation at $94^{\circ} \mathrm{C}$ for $3 \mathrm{~min}, 35$ cycles of denaturation at $94^{\circ} \mathrm{C}$ for $45 \mathrm{~s}$, annealing at $50^{\circ} \mathrm{C}$ for $60 \mathrm{~s}$ and extension at $72^{\circ} \mathrm{C}$ for $90 \mathrm{~s}$, with a final extension of $72^{\circ} \mathrm{C}$ for $10 \mathrm{~min}$ (Caporaso et al., 2011). Amplicons were visualized in agarose gels $(1.5 \% \mathrm{p} / \mathrm{v})$ in $1 \mathrm{X}$ TAE at $100 \mathrm{~V}, 30 \mathrm{~min}$. All PCR products were purified following the protocol of Agentcourt ${ }^{\circledR}$ AMPure ${ }^{\circledR}$ XP.

In the second PCR, $5 \mu \mathrm{L}$ of the previous amplicon were used as the template, with $1 \mu \mathrm{L}(10 \mu \mathrm{M})$ of each of the forward and reverse barcoding primer, $0.1 \mu \mathrm{L}$ of Taq Platinum (Invitrogen), $0.75 \mu \mathrm{L}$ of $\mathrm{MgCl}_{2} 50 \mathrm{mM}$, 2.5 Buffer-Mg 10X, $0.5 \mu \mathrm{L}$ of dNTPs $10 \mathrm{mM}$ and 14.15 $\mu \mathrm{L}$ of Ultrapure Distilled Water (Invitrogen) added. The amplification conditions were the same but with 12 cycles. The final PCR products were purified, and the quality was observed in agarose gels $(1.5 \% \mathrm{p} / \mathrm{v})$.

For the ITS gene library, the first PCR was performed in a final volume of $25 \mu \mathrm{L}$, containing $0.1 \mu \mathrm{L}$ of Taq Platinum (Invitrogen), $1.5 \mu \mathrm{L}$ of $\mathrm{MgSO}_{4} 50 \mathrm{mM}, 2.5$ $\mu \mathrm{L}$ of Buffer-Mg 10X, $0.5 \mu \mathrm{L}$ of dNTPs $10 \mathrm{mM}, 0.5$ $\mu \mathrm{L}(10 \mu \mathrm{M})$ of each forward and reverse primers with adaptor sequences, $2 \mu \mathrm{L}$ of $\mathrm{ADN}$ and $17.4 \mu \mathrm{L}$ of Ultrapure Distilled Water (Invitrogen). The following conditions were used: initial denaturation at $95^{\circ} \mathrm{C}$ for $2 \mathrm{~min}, 35$ cycles of denaturation at $95^{\circ} \mathrm{C}$ for $30 \mathrm{~s}$, annealing at $55^{\circ} \mathrm{C}$ for $30 \mathrm{~s}$ and extension at $72^{\circ} \mathrm{C}$ for 60 $\mathrm{s}$, with a final extension of $72^{\circ} \mathrm{C}$ for $5 \mathrm{~min}$. The amplicons were visualized in agarose gels $(1.5 \% \mathrm{p} / \mathrm{v})$ in $1 \mathrm{X}$
TAE at $100 \mathrm{~V}, 30 \mathrm{~min}$. The procedure for the second step PCR and product purification were as described above, adding $5 \mu \mathrm{L}$ of the amplicon to the mixture and decreasing the cycles to 12 in the thermocycler program.

The purified DNA amplicons were quantified in a NanoDrop $^{\mathrm{TM}} 1000$ Spectrophotometer, pooled and adjusted to the same concentration for the sequencing in the Illumina MiSeq System at the Microbial genomics laboratory of the Molecular Genetics and Antimicrobial Resistance Unit at the Universidad El Bosque (Bogota, Colombia).

The quality of the high throughput sequencing data was analyzed with Fastqc (Blankenberg et al., 2010) and compared to the GenBank database using the Blastn algorithm. Once the microorganisms were identified, a decision matrix was designed to eliminate those species that, according to scientific literature, had ecotoxicological or toxicological risks, keeping those that did not present any risks and that had been reported as having biocontrol activity.

\section{Gnotobiotic system for the selection of potential biocontrol microorganisms}

The biocontrol activity was evaluated following the methodology described by Moreno et al. (2014). Two 13 d-old cape gooseberry seedlings grown from disinfected seeds were placed in a plastic Petri dish (138.9 by $21.1 \mathrm{~cm}$ ) with Gelified Nutrient Medium Agar - agar enriched with microelements $\left(\mathrm{KI}, \mathrm{H}_{3} \mathrm{BO}_{3}\right.$, $\mathrm{MnSO}_{4}, \mathrm{ZnSO}_{4}, \mathrm{Na}_{2} \mathrm{MoO}_{4}$ and $\mathrm{CuSO}_{4}$ ). The seedlings were placed $2 \mathrm{~cm}$ away from the periphery towards the center of the Petri dish (Fig. 1A).

The Biological Control Agent inoculum (BCA) was obtained with cell washing by scraping the surface of culture plates for the bacteria and yeasts (bacterial colonies grown on $\mathrm{LB}$ at $28^{\circ} \mathrm{C}$ for $24 \mathrm{~h}$ and yeast colonies on $\mathrm{YM}$ at $25^{\circ} \mathrm{C}$ for $72 \mathrm{~h}$ ), adjusting the concentration to $1 \cdot 10^{8} \mathrm{UFC} / \mathrm{mL}$ and $1 \cdot 10^{7} \mathrm{UFC} / \mathrm{mL}$, respectively. For the inoculum of the sporulating filamentous fungi, colonies grown in $\mathrm{PDA}$ at $25^{\circ} \mathrm{C}$ for 8 $\mathrm{d}$ were scraped with a $0.1 \%$ Tween 80 solution, and the spore suspension was filtered through 2 layers of sterile muslin to remove mycelial fragments and adjusted to a final concentration of $1 \cdot 10^{6} \mathrm{UFC} / \mathrm{mL}$. The inoculum concentration was determined according to previous reports (Bleve et al., 2006; Sahebani and Hadavi, 2008; Arrebola et al., 2010). The suspensions of non-sporulated fungi were obtained by 


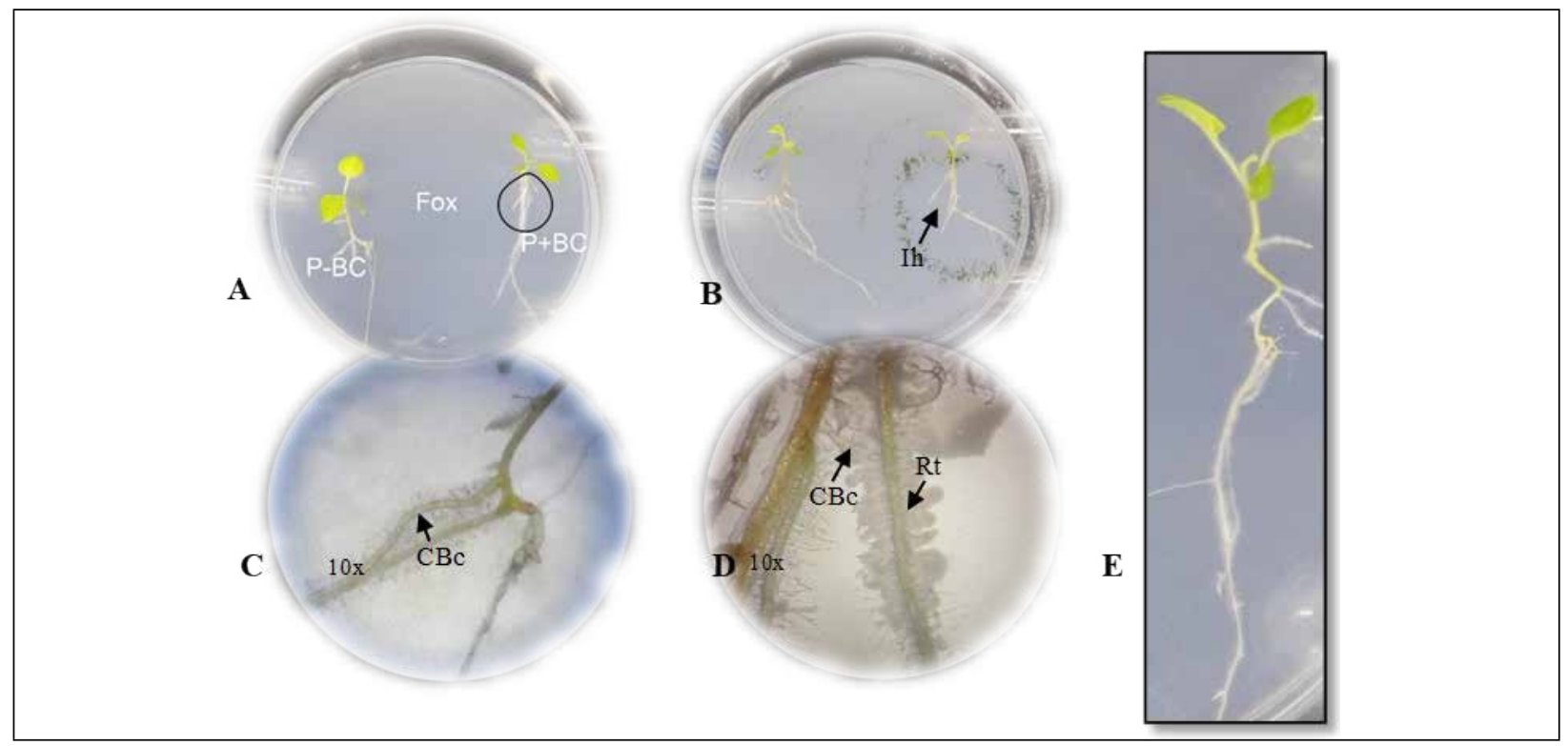

Figure 1. Gnotobiotic model and parameters evaluated in microorganisms with biocontrol potential. A. plant (P) - biocontrol (BC) interaction - Fox in the gnotobiotic model; P-BC: seedling without the biocontrol microorganisms, P + BC: seedling with the biocontrol microorganism, (Fox) Fusarium oxysporum. B. formation of inhibition halo of the pathogen (Ih). C. and D. colonization of the biocontrol microorganisms (CBC) in the radicle (Rt) with 10X magnifications. C., D. biofilm formation with 10X magnifications. E. plant growth.

fragmenting mycelium into an approximate size of $2 \mathrm{~mm}^{2}$ and scraping colonies with a $0.1 \%$ Tween 80 solution and diluting them 100 -fold. A volume of 4 $\mu \mathrm{L}$ of each microorganism was applied to inoculate the seedlings on one plant, on the neck of the stem, which was incubated at $25^{\circ} \mathrm{C}$ for $4 \mathrm{~d}$ (Fig. 1A). The center of the Petri dish was inoculated with $4 \mu \mathrm{L}$ of a Fox suspension adjusted at $5 \cdot 10^{5} \mathrm{UFC} / \mathrm{mL}$, and the dish was incubated at $25^{\circ} \mathrm{C}$ in a vertical position. Three repetitions (Petri dishes) were used for each microorganism with biocontrol potential. Two biological replicates were done.

Three different controls were considered in the experiment: the absolute control that consisted of seedlings without a biocontrol microorganism for Fox; the pathogen control with only seedlings inoculated with Fox; and the relative control consisting of seedlings treated with the biocontrol agent.

Ten days after incubation of the gnotobiotic dishes, the following parameters were evaluated to select microorganisms with biocontrol potential against Fox: (i) symptoms in the seedlings expressed as the presence of chlorotic and roller leaves, (ii) radicle colonization by Fox, (iii) Fox radial growth, (iv) formation of inhibition halo from biocontrol agent against Fox, (v) radicle colonization by fungi or bacteria biofilm formation and growth promotion expressed by total plant length (Fig. 1). A score was assigned to each of the parameters as shown in table 1.

In order to select biocontrol microorganisms, the evaluated parameters were compiled (Tab. 1, Fig. 1). A decision matrix analysis was used that weighed the different factors accordingly to the relative importance assigned to protection characteristics against Fox and plant growth promotion. This selection was based on the following criteria: review of toxicology risks and effects on non-target organisms, results of preliminary tests performed on mass production, results of their biocontrol activity against the pathogen and plant-growth promotion effect (Tab. 1).

\section{Statistical analysis}

A principal component analysis (PCA) was performed to determine the correlations between the data groups corresponding to microorganisms in growth promotion and protection against the pathogen, using R-Studio version 3.3 to detect differences and/or similarities between the microorganisms with potential biocontrol activity. 
Table 1. Parameters evaluated and the percent contribution to selection of microorganism with biocontrol potential in a gnotobiotic system.

\begin{tabular}{|c|c|c|c|c|}
\hline Features & Parameters & Score & Meaning & $\begin{array}{c}\text { Contribution of the } \\
\text { parameter to the } \\
\text { feature }(\%)^{*}\end{array}$ \\
\hline \multirow{10}{*}{ 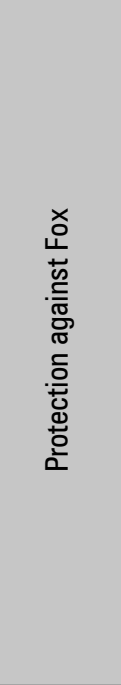 } & \multirow{2}{*}{ Symptoms development } & 0 & Chlorotic and roller leaves & 0 \\
\hline & & 1 & Extended leaves & 40 \\
\hline & \multirow{2}{*}{ Radicle colonization by Fox } & 0 & Fox growth on the radicle & 0 \\
\hline & & 1 & Any growth of Fox on the radicle & 25 \\
\hline & \multirow{2}{*}{ Fox radial growth } & 0 & $\begin{array}{l}\text { Less growth of Fox in the presence of biocontrol agent than in } \\
\text { its absence }\end{array}$ & 15 \\
\hline & & 1 & $\begin{array}{l}\text { Greater growth of Fox in the presence of biocontrol agent than } \\
\text { in its absence }\end{array}$ & 0 \\
\hline & \multirow{2}{*}{$\begin{array}{l}\text { Formation of inhibition halo } \\
\text { from biocontrol agent against } \\
\text { Fox }\end{array}$} & 0 & Not inhibition halo. Radicle colonization by Fox & 0 \\
\hline & & 1 & $\begin{array}{l}\text { Halo produced by the biocontrol agent towards the pathogen. } \\
\text { Not radicle colonization by Fox }\end{array}$ & 15 \\
\hline & \multirow{2}{*}{$\begin{array}{l}\text { Radicle colonization by fungi } \\
\text { or biofilm formation } \\
\text { by bacteria }\end{array}$} & 0 & Any growth of biocontrol agent on the radicle & 0 \\
\hline & & 1 & Growth of biocontrol agent on the radicle & 5 \\
\hline \multirow{2}{*}{ 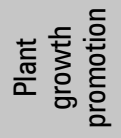 } & \multirow{2}{*}{ Total length plant } & 0 & Less or same growth of plant length without biocontrol agent & 0 \\
\hline & & 1 & Higher plant length growth in presence of biocontrol agent & 100 \\
\hline
\end{tabular}

* Multicriteria analysis for the qualification both characteristics: protection against Fox and growth promotion according to the evaluated parameters.

\section{RESULTS AND DISCUSSION}

\section{Identification and selection of microorganisms with biocontrol potential}

The AGROSAVIA National Microbial Culture Collection for Food and Agriculture provided 64 microorganisms isolated from the rhizosphere of potentially suppressive cape gooseberry soils in Nariño (Tab. 2), 29 were bacteria, and 35 were fungi. Nevertheless, 24 strains (15 bacteria and nine fungi) were discarded because they represented a risk for the environment (E) and for human and animal health (T) and/or they have not been reported as successful biological control agents (CB) (Tab. 2). As a result, 40 microorganisms, of which 14 were bacteria (five from a farm with conventional management and nine from an organic farm). i.e. $35 \%$, and 26 were fungi (13 from each farm), i.e. $65 \%$, which were evaluated in the gnotobiotic model against Fox (Tab. 2).

\section{Evaluation of biocontrol activity of microorganisms}

According to the principal component analysis (PCA), the plant growth promotion, expressed as total plant length (Tab. 1), presented $73.1 \%$ of the variability explained by the two characteristics total plant length and growth promotion (Fig. 2).

The microorganisms with biocontrol potential against Fox were grouped into five different clusters. Cluster 1 grouped $9.10 \%$ of the strains that, albeit with the lowest values for seedling protection (25\%) in all evaluated parameters (formation of inhibition halo against Fox, symptom development, radicle colonization by fungi or biofilm formation by bacteria, radicle colonization by Fox and Fox radial growth), had the greatest effect on promoting growth in the seedlings with an average length of $11.2 \mathrm{~cm}$ (Fig. 2 ; Tab. 3). This cluster contained microorganisms (RY12-Paenibacillus peoriae, RY38-Serratia liquefaciens, 
RY45-Bacillus simplex, and RY43-Pseudomonas chlororaphis) that have strains that have been reported in many studies as plant growth promoting rhizobacteria (PGPR) (Kloepper et al., 1986; Raaijmakers and Weller, 1998; Pieterse et al., 2014; Bubici et al., 2019). Chin-A-Woeng et al. (2003) found that Pseudomonas spp. produces antifungal metabolites, such as phenazine, that favor growth promotion in Cucumis sativus and Solanum lycopersicum plants. Likewise, other bacterial rhizosphere isolates from a potato crop, such as $B$. simplex, induced growth promotion in seedlings (Rete, 2011). S. liquefaciens has been reported as a plant growth-promoting rhizobacteria in cucumber (Kloepper et al., 1986), and P. peoriae has been reported as an antimicrobial agent that counteracts both fungi and phytopathogenic bacteria (Von der Weid et al., 2003). However, in this study, P. peoria had a growth promotion effect but no protection against Fox.

Cluster 2 grouped $15.9 \%$ of the microorganisms that generated a less protective effect on the seedlings (score of 25\%) than the positive effect in terms of growth promotion (an average length of $12.2 \mathrm{~cm}$ ) (Tab. 1; Fig. 2; Tab. 3). This cluster contained the microorganisms RY35-Lysinibacillus sp., RY41-Bacillus

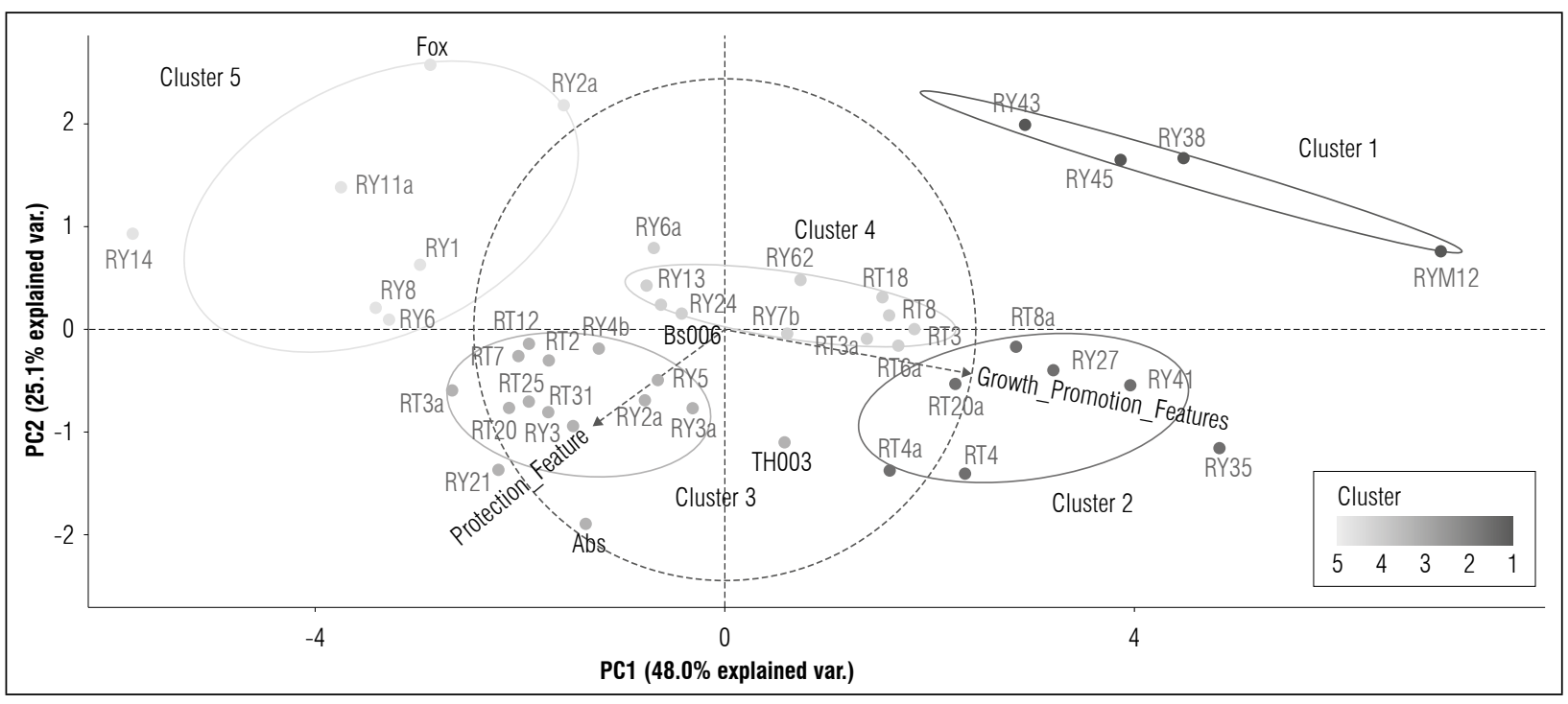

Figures 2. Principal component analysis (PCA) for the grouping of microorganisms with suppressive potential against $F$. oxysporum according to their similarity in the characteristics of biocontrol and growth promotion, obtained from the multicriteria table. The ellipses indicate the $95 \%$ confidence intervals for each cluster.

Table 2. Criteria for microorganism selection with biocontrol potential to be evaluated in a gnotobiotic model.

\begin{tabular}{|c|c|c|c|c|c|c|c|}
\hline \multirow{2}{*}{ Identity of the strain } & \multirow{2}{*}{ Code $^{1}$} & \multicolumn{3}{|r|}{ Toxicological risks } & \multicolumn{2}{|r|}{ Biological control reports } & \multirow{2}{*}{$\begin{array}{c}\text { Selected } \\
\text { isolates } \\
(+,-)\end{array}$} \\
\hline & & E2 & T3 & Reference & CB4 & Reference & \\
\hline $\begin{array}{l}\text { Acinetobacter } \\
\text { rhizosphaerae }\end{array}$ & RTM3 & - & - & Chastre (2003) & + & Indiragandhi et al. (2008) & + \\
\hline Alcaligenes faecalis & RTM40 & + & + & Tena et al. (2015) & - & $\begin{array}{l}\text { Dorman and Deans, (2000) } \\
\text { and Shoda (2000) }\end{array}$ & - \\
\hline Bacillus anthracis & RTM1 & + & + & Spencer (2003) & - & & - \\
\hline Bacillus anthracis & RTM10 & + & + & Spencer (2003) & - & & - \\
\hline Bacillus anthracis & RTM30 & + & + & Spencer (2003) & - & & - \\
\hline Bacillus anthracis & RYM36 & + & + & Spencer (2003) & - & & - \\
\hline Bacillus anthracis & RYM65 & + & + & Spencer (2003) & - & & - \\
\hline
\end{tabular}




\section{Table 2 continuation.}

\begin{tabular}{|c|c|c|c|c|c|c|c|}
\hline \multirow{2}{*}{ Identity of the strain } & \multirow{2}{*}{ Code $^{1}$} & \multicolumn{3}{|r|}{ Toxicological risks } & \multicolumn{2}{|r|}{ Biological control reports } & \multirow{2}{*}{$\begin{array}{l}\text { Selected } \\
\text { isolates } \\
(+,-)\end{array}$} \\
\hline & & E2 & T3 & Reference & CB4 & Reference & \\
\hline Bacillus cereus & RTM2 & + & + & Spencer (2003) & - & & - \\
\hline Bacillus foraminis & RYM27 & - & - & Lagier et al. (2012) & + & Kumar et al. (2015) & + \\
\hline Bacillus simplex & RYM31 & - & - & $\begin{array}{l}\text { de Boer Sietske and Diderichsen } \\
\text { (1991) }\end{array}$ & + & $\begin{array}{l}\text { Gutiérrez-Luna et al. (2010) } \\
\text { and Rashid et al. (2012) }\end{array}$ & + \\
\hline Bacillus simplex & RYM41 & - & - & $\begin{array}{l}\text { de Boer Sietske and Diderichsen } \\
\text { (1991) }\end{array}$ & + & $\begin{array}{l}\text { Gutiérrez-Luna et al. (2010) } \\
\text { and Rashid et al. (2012) }\end{array}$ & + \\
\hline Bacillus simplex & RYM45 & - & - & $\begin{array}{l}\text { de Boer Sietske and Diderichsen } \\
\text { (1991) }\end{array}$ & + & $\begin{array}{l}\text { Gutiérrez-Luna et al. (2010) } \\
\text { and Rashid et al. (2012) }\end{array}$ & + \\
\hline Bacillus sp. & RTM31 & - & - & $\begin{array}{l}\text { de Boer Sietske and Diderichsen } \\
\text { (1991) }\end{array}$ & + & $\begin{array}{l}\text { Handelsman et al. (1990), } \\
\text { He et al. (1994) and Osburn } \\
\text { et al. (1995) }\end{array}$ & + \\
\hline Bacillus sp. & RTM7 & + & + & $\begin{array}{l}\text { de Boer Sietske and Diderichsen } \\
\text { (1991) }\end{array}$ & - & $\begin{array}{l}\text { Handelsman et al. (1990), } \\
\text { He et al. (1994), Osburn et al. } \\
\text { (1995) and Ploper et al. (1992) }\end{array}$ & - \\
\hline Bacillus subtilis & RTM6 & - & - & $\begin{array}{l}\text { de Boer Sietske and Diderichsen } \\
\text { (1991) }\end{array}$ & + & $\begin{array}{l}\text { Bais et al. (2004) and Asaka } \\
\text { and Shoda (2002) }\end{array}$ & + \\
\hline Bacillus subtilis & RYM21 & - & - & $\begin{array}{l}\text { de Boer Sietske and Diderichsen } \\
\text { (1991) }\end{array}$ & + & $\begin{array}{l}\text { Bais et al. (2004) and Asaka } \\
\text { and Shoda (2002) }\end{array}$ & + \\
\hline Bacillus subtilis & RYM25 & - & - & $\begin{array}{l}\text { de Boer Sietske and Diderichsen } \\
\text { (1991) }\end{array}$ & + & $\begin{array}{l}\text { Bais et al. } 2004 \text { and Asaka } \\
\text { and Shoda (2002) }\end{array}$ & + \\
\hline Bacillus thuringiensis & RTM20 & - & - & Ghelardi et al. (2007) & + & Rodríguez et al. (2019) & + \\
\hline Citrobacter sp. & RTM4 & + & + & Deng et al. (2003) & - & & - \\
\hline Citrobacter sp. & RTM5 & + & + & Deng et al. (2003) & + & & + \\
\hline Citrobacter sp. & RTM9 & + & + & Deng et al. (2003) & - & & - \\
\hline Citrobacter sp. & RTM15 & + & + & Deng et al. (2003) & - & & - \\
\hline Lysinibacillus sp. & RYM35 & - & - & & + & $\begin{array}{l}\text { Martínez and Dussán (2018) } \\
\text { and Melnick et al. (2011) }\end{array}$ & + \\
\hline Paenibacillus peoriae & RYM12 & - & - & & + & Von der Weid et al. (2003) & + \\
\hline Pseudomonas chlororaphis & RYM43 & - & - & & + & Gunther et al. (2005) & + \\
\hline Pseudomonas chlororaphis & RYM50 & + & + & & - & López et al. (2012) & - \\
\hline Pseudomonas corrugata & RYM39 & + & + & & - & $\begin{array}{l}\text { Kůdela et al. (2010) and Catara } \\
\text { et al. (2007) }\end{array}$ & - \\
\hline Rahnella sp. & RTM8 & - & - & Hoppe et al. (1993) & + & $\begin{array}{l}\text { Chen et al. (2007), Opelt et } \\
\text { al. (2007) and Felestrino et al. } \\
\text { (2017) }\end{array}$ & + \\
\hline Rhodococcus sp. & RYM13 & - & - & Prescott (1991) & + & (Creason et al., 2014) & + \\
\hline Serratia liquefaciens & RYM38 & - & - & Grohskopf et al. (2001) & + & $\begin{array}{l}\text { Kalbe et al. (1996), Kurze et al. } \\
\text { (2001) and Zahid et al. (2015) }\end{array}$ & + \\
\hline Beauveria bassiana & RY3 & - & - & & + & Ownley et al. (2008) & + \\
\hline $\begin{array}{l}\text { Debaryomyces } \\
\text { vindobonensis }\end{array}$ & RY62 & - & - & & + & Gutiérrez (2017) & + \\
\hline Doratomyces asperulus & RT14 & - & - & $\begin{array}{l}\text { Sandoval-Denis et al. (2016) and } \\
\text { de Hoog et al. (2013) }\end{array}$ & + & Carmarán and Novas (2003) & + \\
\hline
\end{tabular}


Table 2 continuation.

\begin{tabular}{|c|c|c|c|c|c|c|c|}
\hline \multirow{2}{*}{ Identity of the strain } & \multirow{2}{*}{ Code $^{1}$} & \multicolumn{3}{|r|}{ Toxicological risks } & \multicolumn{2}{|r|}{ Biological control reports } & \multirow{2}{*}{$\begin{array}{c}\text { Selected } \\
\text { isolates } \\
(+,-)\end{array}$} \\
\hline & & E2 & T3 & Reference & CB4 & Reference & \\
\hline Fusarium sp. & RT8 & + & + & Gally et al. (2006) & - & & - \\
\hline Fusarium sp. & RT9 & + & + & Gally et al. (2006) & - & & - \\
\hline Fusarium sp. & RT10 & + & + & Gally et al. (2006) & - & & - \\
\hline Fusarium sp. & RT13 & + & + & Gally et al. (2006) & - & & - \\
\hline Gibellulopsis nigrescens & RT19 & + & + & Korolev et al. (2000) & - & Verma and Allison (1970) & - \\
\hline Humicola grisea & RT11 & - & - & de Hoog et al. (2013) & + & Verma and Allison (1970) & + \\
\hline Humicola grisea & RT20 & - & - & de Hoog et al. (2013) & + & Verma and Allison (1970) & + \\
\hline Humicola grisea & RT25 & - & - & de Hoog et al. (2013) & + & $\begin{array}{l}\text { Sobita and Anamika (2011) and } \\
\text { Moreno et al. (2009) }\end{array}$ & + \\
\hline Mucor racemosus & RT3a & - & - & Szaniszlo and Harris (1985) & + & Rai and Saxena (1975) & + \\
\hline Penicillium cremeogriseum & $\mathrm{RT} 2$ & - & - & Refai et al. (2015) & + & Nicoletti et al. (2008) & + \\
\hline Penicillium janthinellum & RT7 & - & - & & + & Marinho et al. (2005) & + \\
\hline Penicillium sp. & RT5 & + & + & & - & Moreno-Limón et al. (2011) & - \\
\hline Penicillium sp. & RT6 & + & + & & - & Moreno-Limón et al. (2011) & - \\
\hline Penicillium sp. & RT11a & + & + & & - & Moreno-Limón et al. (2011) & - \\
\hline Penicillium sp. & RT24 & + & + & & - & Moreno-Limón et al. (2011) & - \\
\hline Plectosphaerella plurivora & RY7B & - & - & & + & Toju et al. (2012) & + \\
\hline Podosporasetosa sp. & RY6 & - & - & & + & Eshraghi et al. (2014) & + \\
\hline Purpureocillium lilacinum & $\mathrm{RT} 12$ & - & - & Rickerts et al. (2000) & + & Anastasiadis et al. (2008) & + \\
\hline Scopulariopsis brevicaulis & RY3a & - & - & & + & Zhang et al. (2015) & + \\
\hline Trichoderma gamsii & RT4 & - & - & & + & Zhang et al. (2015) & + \\
\hline Trichoderma gamsii & RY2a & - & - & & + & Zhang et al. (2015) & + \\
\hline Trichoderma gamsii & RY4B & - & - & & + & Zhang et al. (2015) & + \\
\hline Trichoderma ghanense & RY6a & - & - & Druzhinina et al. (2011) & + & Bayman et al. (2011) & + \\
\hline Trichoderma koningiopsis & RT3 & - & - & Kuhls et al. (1999) & + & $\begin{array}{l}\text { Sobita and Anamika, (2011) and } \\
\text { Moreno et al. (2009) }\end{array}$ & + \\
\hline Trichoderma koningiopsis & RT8 & - & - & & + & $\begin{array}{l}\text { Sobita and Anamika (2011) and } \\
\text { Moreno et al. (2009) }\end{array}$ & + \\
\hline Trichoderma koningiopsis & RY1 & - & - & Kuhls et al. (1999) & + & $\begin{array}{l}\text { Sobita and Anamika (2011) and } \\
\text { Moreno et al. (2009) }\end{array}$ & + \\
\hline Trichoderma sp. & RT4a & - & - & Kuhls et al. (1999) & + & Zhang et al. (2015) & + \\
\hline Trichoderma sp. & RY2 & - & - & Kuhls et al. (1999) & + & Zhang et al. (2015) & + \\
\hline Trichoderma viride & RY5 & - & - & Kuhls et al. (1999) & + & $\begin{array}{l}\text { Martínez-Medina et al. (2014) } \\
\text { and Banaay et al. (2012) }\end{array}$ & + \\
\hline Trichosporon sp. & RY8 & - & - & Kuhls et al. (1999) & + & Zhang et al. (2015) & + \\
\hline Umbelopsis sp. & RT18 & - & - & Rodríguez et al. (2010) & + & Korolev et al. (2000) & + \\
\hline
\end{tabular}

${ }^{1} \mathrm{RT}$, microorganisms isolated from the rhizosphere of the farm with conventional management; RY, microorganisms isolated from the rhizosphere of the farm with organic management. $E^{2}(+)$, presence of ecotoxicological risk; $E^{2}(-)$, absence of ecotoxicological risk. $T^{3}(+)$, presence of toxicological risk; $T^{3}(-)$, absence of toxicological risk. $C B^{4}(+)$, successful reports of biocontrol activity; $C B^{4}(-)$, absence of unsuccessful reports of biocontrol activity. The selected microorganisms are highlighted in the table and are indicated with $(+)$ and unselected with (-). 
Table 3. Values of contribution to the selection of microorganism with and without a biocontrol potential agent in a gnotobiotic system.

\begin{tabular}{|c|c|c|c|c|c|}
\hline Code & Strain & Cluster & $\begin{array}{c}\text { Protection against } \\
\text { Fox }+\mathrm{BC} \\
(\%)\end{array}$ & $\begin{array}{l}\text { Growth promotion } \\
\text { Fox }+ \text { BC } \\
(\%)\end{array}$ & $\begin{array}{l}\text { Growth promotion } \\
\text { Fox }+ \text { BC } \\
(\mathrm{cm})\end{array}$ \\
\hline $\mathrm{RY} 12$ & Paenibacillus peoriae & 1 & 25 & 100 & 9.4 \\
\hline RY38 & Serratia liquefaciens & 1 & 25 & 100 & 9.2 \\
\hline RY45 & Bacillus simplex & 1 & 25 & 100 & 13.0 \\
\hline RY43 & Pseudomonas chlororaphis & 1 & 25 & 100 & 13.0 \\
\hline RY35 & Lysinibacillus sp. & 2 & 25 & 100 & 10.6 \\
\hline RY41 & Bacillus simplex & 2 & 25 & 100 & 12.4 \\
\hline RY27 & Bacillus foraminis & 2 & 25 & 100 & 11.6 \\
\hline RT8a & Rahnella sp. & 2 & 25 & 100 & 11.3 \\
\hline RT20a & Bacillus thuringiensis & 2 & 25 & 100 & 13.1 \\
\hline RT4a & Trichoderma sp. & 2 & 25 & 100 & 11.9 \\
\hline RT4 & Trichoderma gamsii & 2 & 25 & 100 & 14.6 \\
\hline Abs & Absolulo & 3 & 75 & 100 & 9.6 \\
\hline TH003 & Trichoderma koningiopsis & 3 & 60 & 100 & 8.2 \\
\hline RY21 & Bacillus subtilis & 3 & 60 & 100 & 10.9 \\
\hline RY3a & Scopulariopsis brevicaulis & 3 & 60 & 100 & 10.1 \\
\hline RY5 & Trichoderma viride & 3 & 60 & 100 & 8.8 \\
\hline RY2a & Trichoderma gamsii & 3 & 60 & 100 & 8.4 \\
\hline RY4b & Trichoderma gamsii & 3 & 60 & 100 & 8.2 \\
\hline RY3 & Beauveria bassiana & 3 & 50 & 100 & 9.3 \\
\hline RT31 & Bacillus sp. & 3 & 55 & 100 & 9.7 \\
\hline RT3a & Mucor racemosus & 3 & 55 & 100 & 8.8 \\
\hline RT20 & Chaetomiaceae sp. & 3 & 55 & 100 & 9.0 \\
\hline RT25 & Chaetomiaceae sp. & 3 & 55 & 100 & 9.1 \\
\hline $\mathrm{RT} 2$ & Penicillium cremeogriseum & 3 & 55 & 100 & 8.3 \\
\hline RT7 & Penicillium janthinellum & 3 & 55 & 100 & 9.7 \\
\hline $\mathrm{RT} 12$ & Purpureocillium lilacinum & 3 & 75 & 100 & 10.4 \\
\hline Bs006 & Bacillus subtilis & 4 & 60 & 100 & 9.3 \\
\hline RY25 & Bacillus subtilis & 4 & 60 & 100 & 12.3 \\
\hline RY13 & Rhodococcus sp. & 4 & 60 & 100 & 9.2 \\
\hline RY6a & Podospora setosa & 4 & 40 & 100 & 9.0 \\
\hline RY62 & Debaryomyces vindobonensis & 4 & 40 & 100 & 9.6 \\
\hline RY7b & Plectosphaerella plurivora & 4 & 60 & 100 & 8.7 \\
\hline $\mathrm{RT} 3$ & Acinetobacter rhizosphaerae & 4 & 45 & 100 & 11.5 \\
\hline RT6 & Bacillus subtilis & 4 & 60 & 100 & 9.0 \\
\hline RT3 & Trichoderma koningiopsis & 4 & 60 & 100 & 9.6 \\
\hline RT8 & Trichoderma koningiopsis & 4 & 75 & 100 & 11.2 \\
\hline $\mathrm{RT} 18$ & Umbelopsis sp. & 4 & 45 & 100 & 11.0 \\
\hline Fox & Fusarium oxysporum & 5 & 25 & 0 & 8.2 \\
\hline
\end{tabular}


Table 3, continuation.

\begin{tabular}{|c|c|c|c|c|c|}
\hline Code & Strain & Cluster & $\begin{array}{c}\text { Protection against } \\
\text { Fox }+ \text { BC } \\
(\%)\end{array}$ & $\begin{array}{c}\text { Growth promotion } \\
\text { Fox }+ \text { BC } \\
(\%)\end{array}$ & $\begin{array}{l}\text { Growth promotion } \\
\text { Fox }+\mathrm{BC} \\
(\mathrm{cm})\end{array}$ \\
\hline RY2 & Trichoderma sp. & 5 & 25 & 0 & 6.4 \\
\hline RY1 & Trichoderma koningiopsis & 5 & 25 & 100 & 8.3 \\
\hline RY6 & Trichoderma ghanense & 5 & 25 & 0 & 7.9 \\
\hline RY8 & Trichosporon lignicola & 5 & 25 & 0 & 6.5 \\
\hline RT11a & Humicola grisea & 5 & 5 & 0 & 7.6 \\
\hline RT14 & Doratomyces asperulus & 5 & 25 & 0 & 5.5 \\
\hline
\end{tabular}

* The contribution of protection characteristics against Fox and promotion of growth in seedlings without biocontrol was zero because of the absence of the microorganism.

simplex, RY27-Bacillus foraminis, RT8a-Rahnella sp., RT20a-Bacillus thuringiensis, RT4a-Trichoderma sp. and RT4-Trichoderma gamsii. Previous studies have reported the presence of $B$. simplex and $R$. aquatilis in the rhizosphere of Vitis spp., which facilitate nitrogen fixation and promote plant growth in Solanum tuberosum and Vitis spp. (Chen et al., 2007; Velivelli et al., 2015). Singh et al. (2015) reported that B. foraminis, not only exerts a protective effect against $F u$ sarium sp., but also favors the promotion of growth in Zea mays. Additionally, L. fusiformis, Lysinibacillus spp. and B. thuringiensis have been described as potential biocontrol agents of $F$. oxysporum f. sp. ciceri race 1 in Cicer arietinum (Singh et al., 2014). Similar results were found in the present study. Moreover, this study confirmed the biocontrol activity of Trichoderma sp. since T. gamsii and other species from this genus had a control effect against Fox in the cape gooseberry seedlings (Fig. 1B).

Cluster 3 included $34.1 \%$ of the microorganisms with high values in terms of seedling protection, a high score of $50 \%$ in these parameters, and a positive effect in terms of growth promotion (average length of $9.2 \mathrm{~cm}$ ), but there were no differences between plant length (Tab. 1; Fig. 2; Tab. 3). This cluster contained microorganisms with biocontrol potential, such as TH003-Trichoderma koningiopsis, RY21-Bacillus subtilis, RY3-Scopulariopsis brevicaulis, RY5-Trichoderma viride, RY2-T. gamsii, RY4b-Trichoderma gamsii, RY3Beauveria bassiana, RT31-Bacillus sp., RT3a-Mucor racemosus, RT20-Humicola grisea, RT25-H. grisea, RT2-Penicillium cremeogriseum, RT7-Penicillium janthinellum and RT12-Purpureocillium lilacinum. Some species of the Trichoderma genus are effective biocontrol agents (Schirmböck et al., 1994; Lorito et al., 1996; Howell, 2003), and T. koningiopsis, T. viride, T. gamsii and $S$. brevicaulis have been reported as antagonistic agents of Fusarium culmorum in Zea mays (Luongo et al., 2005). The Th003 strain of T. koningiopsis is the active ingredient of Tricotec $^{\circledR}$, a product registered in Colombia by Agrosavia for the control of $F$. oxysporum f. sp. lycopersici in tomato crops (Cotes et al., 2018). On the other hand, B. bassiana, M. racemosus and Penicillium spp. have been reported as mycoparasites on F. oxysporum f. sp. radicis-lycopersici (PalmaGuerrero et al., 2008). H. grisea and Purpureocillium sp. have been reported as biocontrol agents because of the production of antibiotics (Hubbard et al., 1982; Di Pietro et al., 1992) that inhibit pathogens such as F. culmorum and Pythium ultimum (Galindo-Flores et al., 2005). Asaka and Shoda (2002) found that B. subtilis produces antibiotics, such as iturin $A$ and surfactin, that counteract pathogens such as Rhizoctonia solani in tomato plants.

Cluster 4 concentrated $25 \%$ of the microorganisms that generated the highest protection values against Fox (Score highest than 60\%) and showed a positive effect in growth promotion (average length of $10 \mathrm{~cm}$ ) (Tab. 1; Fig. 2; Tab. 3). The microorganisms in this cluster were Bs006-Bacillus velezensis, RY25Bacillus subtilis, RY13-Rhodococcus sp., RY6-Podospora setosa, RY62-Debaryomyces vindobonensis, RY7b-Plectosphaerella plurivora, RT3-Acinetobacter rhizosphaerae, RT6-Bacillus subtilis, RT3-Trichoderma koningiopsis, RT8-Trichoderma koningiopsis, and RT18-Umbelopsis sp. Previous studies have shown that Bs006, a strain of $B$. velezensis, is an excellent Fox inhibiting microorganism because of antibiotic secretions (Moreno et al., 2014) and that Rhodococcus sp. inhibits Pythium aphanidermatum under in vitro conditions because the enzymes are capable of degrading the cell wall (El-Tarabily, 2006), which could explain the control 
activity of this microorganism against Fox. In contrast, Debaryomyces sp., Plectosphaerella sp., Umbelopsis sp. and Acinetobacter sp. have been widely studied as growth promoters (Rokhbakhsh-Zamin et al., 2011; Zhao et al., 2014), and Podospora sp. has been reported as an abundant microorganism in healthy Musa sp. and Pyrus sp. soils and has been associated with the suppression of vascular wilt caused by Fox (Xu et al., 2012; Huang et al., 2017).

Cluster 5 represented $15.90 \%$ of the microorganisms, which did not generate a protection effect against the pathogen in the seedlings or an effect on growth promotion (average length of $7.2 \mathrm{~cm}$ ) (Fig. 2; Tab. 3). This group had the treatment that only contained Fox (pathogenic control). This cluster contained the microorganisms RY2-Trichoderma sp., RY1-Trichoderma koningiopsis, RY6-Trichoderma ghanense, RY8-Trichosporon lignicola, RT11-H. grisea and RT14-Doratomyces asperulus. In contrast to cluster 4 , the two strains of Trichoderma from this group did not have a protective effect against the pathogen. Di Pietro et al. (1992) reported that $H$. grisea and $D$. asperulus are biocontrol agents because of the production of antimicrobial substances that counteract $F$. culmorum. Nevertheless, the strains in this cluster did not protect against the pathogen. On the contrary, some of them favored Fox because they allowed abundant growth and development of vascular wilt symptoms.

\section{CONCLUSION}

The biocontrol activity and growth responses of the cape gooseberries to the treatments with the evaluated rhizospheric microorganisms varied with the isolate-type and the origin of the isolates. The majority of the bacteria obtained from the organic farm expressed a biocontrol activity and positively affected plant growth, whereas the fungal isolates with a biocontrol activity and plant growth promotion were similar for the two farms. This effect reflects the capability of different microorganism species to counteract this pathogen and promote plant growth. However, a practical application of these results should be further evaluated in field experiments. Based on our results, Bs006-Bacillus velezensis, RY25Bacillus subtilis, RY13-Rhodococcus sp., RY6-Podospora setosa, RY62-Debaryomyces vindobonensis, RY7b-Plectosphaerella plurivora, RT3-Acinetobacter rhizosphaerae, RT6-Bacillus subtilis, RT3-Trichoderma koningiopsis, RT8-Trichoderma koningiopsis, are RT18-Umbelopsis sp. are promising F. oxysporum control treatments for cape gooseberries (more than 60\%), which should be evaluated both individually and in consortia under greenhouse conditions.

\section{Acknowledgments}

This study was carried out under the project "Comprehensive development of sustainable production models for the cultivation of cape gooseberry in Colombia", which was part of the research agenda of the Corporación Colombiana de Investigación Agropecuaria (Agrosavia) during 2013-2017, as supported by the Ministerio de Agricultura y Desarrollo Rural - MADR through resources for the Corporación Colombiana de Investigación Agropecuaria (Agrosavia). We are also grateful to Agrosavia and the Universidad Nacional de Colombia, Bogota Campus, for providing resources and support during the development of this study, both in the experiment phase and in the analysis of results. We also thank the researchers from Agrosavia, Luisa Fernanda Izquierdo and Cindy Nayibe Mejía for their work and for providing the isolates evaluated in this project.

Conflict of interests: The authors declare that this research was conducted in the absence of any commercial or financial relationships that could be construed as a potential conflict of interest. A.M Cotes conceived the research idea. D.S. García carried out the experiments and drafted the manuscript under the advice of A.M. Cotes and A. Gonzalez, who contributed to the date analysis and interpretation, as well as critical revisions and approval of the final version of the manuscript. A. Caro and L.L. Dávila contributed to the molecular identification of the isolates. Each author contributed drafts of specific sections of the manuscript and repeatedly edited the manuscript.

Author's note: The microorganisms used in this study were provided by the collection of bacteria and fungi from Agrosavia, obtained in a previous sampling conducted under the guidelines indicated in resolution 1466 of December 03, 2014 of ANLA, Colombia.

\section{BIBLIOGRAPHIC REFERENCES}

Agronet. 2018. Área, producción y rendimiento nacional por cultivo. In: https://www.agronet.gov.co/estadisti$\mathrm{ca} /$ Paginas/home.aspx? $\operatorname{cod}=1$; consulted: April, 2019.

Akköprü, A. and S. Demir. 2005. Biological control of Fusarium wilt in tomato caused by Fusarium oxysporum 
f. sp. lycopersici by AMF Glomus intraradices and some rhizobacteria. J. Phytopathol. 153(9), 544-550. Doi: 10.1111/j.1439-0434.2005.01018.x

Anastasiadis, I.A., I.O. Giannakou, D.A. Prophetou-Athanasiadou, and S.R. Gowen. 2008. The combined effect of the application of a biocontrol agent Paecilomyces lilacinus, with various practices for the control of rootknot nematodes. Crop Prot. 27(3-5), 352-361. Doi: 10.1016/j.cropro.2007.06.008

Arrebola, E., R. Jacobs, and L. Korsten. 2010. Iturin: A is the principal inhibitor in the biocontrol activity of Bacillus amyloliquefaciens PPCB004 against postharvest fungal pathogens. J. Appl. Microbiol. 108(2), 386-395. Doi: 10.1111/j.1365-2672.2009.04438.x

Asaka, O. and M. Shoda. 2002. Biocontrol of Rhizoctonia solani damping-off of tomato with Bacillus subtilis RB14. Appl. Environ. Microbiol. 62(11), 4081-4085. Doi: 10.1128/aem.62.11.4081-4085.1996

Bais, H.P., R. Fall, and J.M. Vivanco. 2004. Biocontrol of Bacillus subtilis against infection of arabidopsis roots by Pseudomonas syringae is facilitated by biofilm formation and surfactin production. Plant Physiol. 134(1), 307-319. Doi: 10.1104/pp.103.028712

Banaay, C.G.B., C.V. Cuevas, and C.M. Vera. 2012. Trichoderma ghanense promotes plant growth and controls disease caused by Pythium arrhenomanes in seedlings of aerobic rice variety Apo. Philipp. Agric. Scientist 95(2), 175-184.

Bayman, P., L.L. Lebron, R.L. Tremblay, and D.J. Lodge. 1997. Variation in endophytic fungi from roots and leaves of Lepanthes (Orchidaceae). New Phytol. 135(1), 143-149. Doi: 10.1046/j.1469-8137.1997.00618.x

Bennett, R.S., W. O'neill, L. Smith, R.B. Hutmacher, and R.S. Bennett. 2011. Plant pathology and nematology: Activity of commercial detergents against conidia and chlamydospores of Fusarium oxysporum f. sp. vasinfectum. J. Cotton Sci. 15(2), 162-169.

Blankenberg, D., A. Gordon, G. Von Kuster, N. Coraor, J. Taylor, A. Nekrutenko, and G. Team. 2010. Manipulation of FASTO data with galaxy. Bioinformatics 26(14), 1783-1785. Doi: 10.1093/bioinformatics/ btq281

Bleve, G., F. Grieco, G. Cozzi, A. Logrieco, and A. Visconti. 2006. Isolation of epiphytic yeasts with potential for biocontrol of Aspergillus carbonarius and A. niger on grape. Int. J. Food Microbiol. 108(2), 204-209. Doi: 10.1016/j.ijfoodmicro.2005.12.004

Bubici, G., M. Kaushal, M.I. Prigigallo, C.G.L. Cabanás, and J. Mercado-Blanco. 2019. Biological control agents against Fusarium wilt of banana. Front. Microbiol. 10, 616. Doi: 10.3389/fmicb.2019.00616

Caporaso, J.G., C.L. Lauber, W.A. Walters, D. Berg-Lyons, C.A. Lozupone, P.J. Turnbaugh, N. Fierer, and R. Knight. 2011. Global patterns of $16 \mathrm{~S}$ rRNA diversity at a depth of millions of sequences per sample. Proc. Natl. Acad. Sci. USA 108(Suppl. 1), 4516-4522. Doi: 10.1073/pnas.1000080107

Carmarán, C.C. and M.V. Novas. 2003. A review of Spegazzini taxa of Periconia and Sporocybe after over 115 years. Fungal Divers. 14, 67-76.

Carvalho, D.D.C., M. Lobo Junior, I. Martins, P.W. Inglis, and S.C.M. Mello. 2014. Biological control of fusarium oxysporum f. sp. phaseoli by Trichoderma harzianum and its use for common bean seed treatment. Trop. Plant Pathol. 39(5), 384-391. Doi: 10.1590/ S1982-56762014000500005

Catara, V. 2007. Pseudomonas corrugata: plant pathogen and/ or biological resource? Mol. Plant Pathol. 8(3), 233244. Doi: 10.1111/j.1364-3703.2007.00391.x

Chastre, J. 2003. Infections due to Acinetobacter baumannii in the ICU. Semin. Respir. Crit. Care Med. 24(1), 069078. Doi: 10.1055/s-2003-37918

Chen, F., Y.B. Guo, J.H. Wang, J.Y. Li, and H.M. Wang. 2007. Biological control of grape crown gall by Rahnella aquatilis HX2. Plant Dis. 91(8), 957-963. Doi: 10.1094/ PDIS-91-8-0957

Chin-A-Woeng, T.F.C., G.V. Bloemberg, and B.J.J. Lugtenberg. 2003. Phenazines and their role in biocontrol by Pseudomonas bacteria. New Phytol. 157(3), 503-523. Doi: 10.1046/j.1469-8137.2003.00686.x

Cotes, A.M., C.A. Moreno-Velandia, C. Espinel, L. Villamizar, and M. Gómez. 2018. Biological control of tomato Fusarium wilt and whiteflies with two fungal biopesticides. Acta Hortic. 1207, 129-138. Doi: 10.17660/ ActaHortic.2018.1207.17

Creason, A.L., O.M. Vandeputte, E.A. Savory, E.W. II Davis, M.L. Putnam, E. Hu, D. Swader-Hines, A. Mol, M. Baucher, E. Prinsen, M. Zdanowska, S.A. Givan, M. El Jaziri, J.E. Loper, T. Mahmud, and J.H. Chang. 2014. Analysis of genome sequences from plant pathogenic Rhodococcus reveals genetic novelties in virulence loci. PLoS ONE 9(7), e101996. Doi: 10.1371/journal. pone.0101996

De Boer Sietske, A. and B. Diderichsen. 1991. On the safety of Bacillus subtilis and B. amyloliquefaciens: a review. Appl. Microbiol. Biotechnol. 36(1), 1-4. Doi: 10.1007/ BF00164689

De Hoog, G.S., S.A. Ahmed, M.J. Najafzadeh, D.A. Sutton, M.S. Keisari, A.H. Fahal, U. Eberhardt, G.J. Verkleij, L. Xin, B. Stielow, and W.W.J. van de Sande. 2013. Phylogenetic findings suggest possible new habitat and routes of infection of human eumyctoma. PLoS Negl. Trop. Dis. 7(5), e2229. Doi: 10.1371/journal. pntd.0002229

Deng, W., B.A. Vallance, Y. Li, J.L. Puente, and B.B. Finlay. 2003. Citrobacter rodentium translocated intimin receptor (Tir) is an essential virulence factor needed for 
actin condensation, intestinal colonization and colonic hyperplasia in mice. Mol. Microbiol. 48(1), 95-115. Doi: 10.1046/j.1365-2958.2003.03429.x

Di Pietro, A., M. Gut-Rella, J.P. Pachlatko, and F.J. Schwinn. 1992. Role of Antibiotics Produced by Chaetomium globosum in biocontrol of Pythium ultimum, a causal agent of damping-off. Phytopathology 82(2), 131. Doi: 10.1094/phyto-82-131

Dorman, H.J.D. and S.G. Deans. 2000. Antimicrobial agents from plants: Antibacterial activity of plant volatile oils. J. Appl. Microbiol. 88(2), 308-316. Doi: 10.1046/j.1365-2672.2000.00969.x

Druzhinina, I.S., V. Seidl-Seiboth, A. Herrera-Estrella, B.A. Horwitz, C.M. Kenerley, E. Monte, P.K. Mukherjee, S. Zeilinger, I.V. Grigoriev, and C.P. Kubicek. 2011. Trichoderma: The genomics of opportunistic success. Nat. Rev. Microbiol. 9(10), 749-759. Doi: 10.1038/ nrmicro2637

El-Tarabily, K.A. 2006. Rhizosphere-competent isolates of streptomycete and non-streptomycete actinomycetes capable of producing cell-wall-degrading enzymes to control Pythium aphanidermatum damping-off disease of cucumber. Can. J. Bot. 84, 211-222. Doi: 10.1139/ B05-153

Enciso-Rodríguez, F.E., C. González, E.A. Rodríguez, C.E. López, D. Landsman, L.S. Barrero, and L. Mariño-Ramírez. 2013. Identification of immunity related genes to study the Physalis peruviana - Fusarium oxysporum pathosystem. PLoS ONE 8(7), 68500. Doi: 10.1371/ journal.pone.0068500

Eshraghi, L., J.P. Anderson, N. Aryamanesh, J.A. McComb, B. Shearer, and G.E. Giles. 2014. Defence signalling pathways involved in plant resistance and phosphite-mediated control of Phytophthora cinnamomi. Plant Mol. Biol. Rep. 32(2), 342-356. Doi: 10.1007/ s11105-013-0645-5

Felestrino, E.B., I.F. Santiago, L.S. Freitas, L.H. Rosa, S.P. Ribeiro, and L.M. Moreira. 2017. Plant growth promoting bacteria associated with Langsdorffia hypogaea-Rhizosphere-Host biological interface: A neglected model of bacterial prospection. Front. Microbiol. 8, 172. Doi: 10.3389/fmicb.2017.00172

Fischer, G. and L.M. Melgarejo. 2020. The ecophysiology of cape gooseberry (Physalis peruviana L.) - an Andean fruit crop. A review. Rev. Colomb. Cienc. Hortic. 14(1), 76-89. Doi: 10.17584/rcch.2020v14i1.10893

Galindo, J.R. and L.M. Pardo. 2010. Uchuva (Physalis peruviana): Producción y manejo poscosecha. Cámara de Comercio, Bogota.

Galindo-Flores, H., J.C. Martínez-Álvarez, E. Nava-Pérez, R.S. García-Estrada, and I.E. Maldonado-Mendoza. 2005. A saprotrophic fungal isolate from northern Sinaloa, Mexico, with homology to members of the chaetomiaceae behaves as an antagonist of phytopathogenic fungi in vitro. Rev. Mex. Fitopatol. 23(2), 130-139.

Gally, T., B.A. González, and F. Pantuso. 2006. Efecto conjunto de Fusarium sp. y Phomopsis sp., patógenos transmitidos por las semillas en plántulas de soja [Glycine $\max ($ L.) Merrill]. Rev. Mex. Fitopatol. 24(2), 156-158.

Ghelardi, E., F. Celandroni, S. Salvetti, E. Fiscarelli, and S. Senesi. 2007. Bacillus thuringiensis pulmonary infection: critical role for bacterial membrane-damaging toxins and host neutrophils. Microb. Infect. 9(5), 591598. Doi: 10.1016/j.micinf.2007.02.001

Giraldo-Betancourt, C., E.A. Velandia-Sánchez, G. Fischer, S. Gómez-Caro, and L.-J. Martínez. 2020. Hyperspectral response of cape gooseberry (Physalis peruviana L.) plants inoculated with Fusarium oxysporum f. sp. physali for vascular wilt detection. Rev. Colomb. Cienc. Hortic. 14(3). Doi: 10.17584/rcch.2020v14i3.10938

González, C. and L.S. Barrero. 2011. Estudio de la marchitez vascular de la uchuva para el mejoramiento genético del cultivo. Cámara de Comercio, Bogota.

Grohskopf, L., V. Roth, D. Feikin, M. Arduino, L. Carson, J. Tokars, S.C. Holt, B.J. Jensen, R.E. Hoffman, and W.R. Jarvis. 2001. Serratia liquefaciens bloodstream infections from contamination of epoetin alfa at a hemodialysis center. N. Engl. J. Med. 344, 1491-1497. Doi: 10.1056/nejm200105173442001

Gunther IV, N.W., A. Nuñez, W. Fett, and D.K.Y. Solaiman. 2005. Production of rhamnolipids by Pseudomonas chlororaphis, a nonpathogenic bacterium. Appl. Environ. Microbiol. 71(5), 2288-2293. Doi: 10.1128/ AEM.71.5.2288-2293.2005

Gutiérrez-Luna, F.M., J. López-Bucio, J. Altamirano-Hernández, E. Valencia-Cantero, H.R. De La Cruz, and L. Macías-Rodríguez. 2010. Plant growth-promoting rhizobacteria modulate root-system architecture in Arabidopsis thaliana through volatile organic compound emission. Symbiosis 51(1), 75-83. Doi: 10.1007/ s13199-010-0066-2

Gutiérrez, E. 2017. Caracterización de los mecanismos antagónicos de Debaryomyces hansenii contra Colletotrichum gloersporioides y su efecto en la protección poscosecha en papaya var. Maradol. MSc thesis. Centro de Investigaciones Biológicas del Noroeste, La Paz, Mexico.

Haglund, W.A. and J.M. Kraft. 2001. Fusarium wilt. In: Compendium of pea diseases and pests. American Phytopathological Society, St. Paul, MN.

Handelsman, J., S. Raffel, E.H. Mester, L. Wunderlich, and C.R. Grau. 1990. Biological control of damping-off of alfalfa seedlings with Bacillus cereus UW85. Appl. Environ. Microbiol. 56(3), 713-718. Doi: 10.1128/ aem.56.3.713-718.1990

Hassanien, M.F.R. 2011. Physalis peruviana: A rich source of bioactive phytochemicals for functional foods and 
pharmaceuticals. Food Rev. Int. 27(3), 259-273. Doi: 10.1080/87559129.2011.563391

He, H., L.A. Silo-Suh, J. Handelsman, and J. Clardy. 1994. Zwittermicin A: an antifungal and plant protection agent from Bacillus cereus. Tetrahedron Lett. 35(16), 2499-2502. Doi: 10.1016/S0040-4039(00)77154-1

Hoppe, J.E., M. Herter, S. Aleksic, T. Klingebiel, and D. Niethammer. 1993. Catheter-related Rahnella aquatilis bacteremia in a pediatric bone marrow transplant recipient. J. Clin. Microbiol. 31(7), 1911-1912. Doi: 10.1128/JCM.31.7.1911-1912.1993

Howell, C.R. 2003. Mechanisms employed by Trichoderma species in the biological control of plant diseases: The history and evolution of current concepts. Plant Dis. 87(1), 4-10. Doi: 10.1094/PDIS.2003.87.1.4

Huang, P., L. de-Bashan, T. Crocker, J.W. Kloepper, and Y. Bashan. 2017. Evidence that fresh weight measurement is imprecise for reporting the effect of plant growth-promoting (rhizo)bacteria on growth promotion of crop plants. Biol. Fert. Soils 53(2), 199-208. Doi: 10.1007/s00374-016-1160-2

Hubbard, J.P., G.E. Harman, and C.J. Eckenrode. 1982. Interaction of a biological control agent, Chaetomium globosum, with seed coat microflora. Can. J. Microbiol. 28(4), 431-437. Doi: 10.1139/m82-065

ICA, Instituto Colombiano Agropecuario. 2020. Fertilizantes y bioinsumos agrícolas. In: https://www. ica.gov.co/getdoc/d3612ebf-a5a6-4702-8d4b-8427c1cdaeb1/registros-nacionales-pqua-15-04-09.aspx; consulted: December, 2020.

Indiragandhi, P., R. Anandham, M. Madhaiyan, and T.M. As. 2008. Characterization of plant growth-promoting traits of bacteria isolated from larval guts of Diamondback moth Plutella xylostella (Lepidoptera: Plutellidae). Curr. Microbiol. 56(4), 327-333. Doi: 10.1007/s00284-007-9086-4

Kalbe, C., P. Marten, and G. Berg. 1996. Strains of the genus Serratia as beneficial rhizobacteria of oilseed rape with antifungal properties. Microbiol. Res. 151(4), 433-439. Doi: 10.1016/S0944-5013(96)80014-0

Kloepper, J.W., F.M. Scher, M. Laliberté, and B. Tipping. 1986. Emergence-promoting rhizobacteria: Description and implications for agriculture. pp. 155164. In: Swinburne, T.R. (eds.). Iron, siderophores, and plant diseases. NATO ASI Series (Series A: Life Sciences). Vol. 117. Springer, Boston, MA. Doi: 10.1007/978-1-4615-9480-2_17

Köhl, J., R. Kolnaar, and W.J. Ravensberg. 2019. Mode of action of microbial biological control agents against plant diseases: Relevance beyond efficacy. Front. Plant Sci. 10, 845. Doi: 10.3389/fpls.2019.00845

Korolev, N., J. Katan, and T. Katan. 2000. Vegetative compatibility groups of Verticillium dahliae in Israel:
Their distribution and association with pathogenicity. Phytopathology 90(5), 529-536. Doi: 10.1094/ PHYTO.2000.90.5.529

Kůdela, V., V. Krejzar, and I. Pánková. 2010. Pseudomonas corrugata and Pseudomonas marginalis associated with the collapse of tomato plants in Rockwool slab hydroponic culture. Plant Prot. Sci. 46(1), 1-11. Doi: 10.17221/44/2009-PPS

Kuhls, K., E. Lieckfeldt, T. Börner, and E. Guého. 1999. Molecular reidentification of human pathogenic Trichoderma isolates as Trichoderma longibrachiatum and Trichoderma citrinoviride. Med. Mycol. 37(1), 25-33. Doi: 10.1046/j.1365-280X.1999.00197.x

Kumar, R.M., G. Kaur, A. Kumar, M. Bala, N.K. Singh, N. Kaur, N. Kumar, and S. Mayilraj. 2015. Taxonomic description and genome sequence of Bacillus campisalis sp. nov., a member of the genus Bacillus isolated from a solar saltern. Int. J. Syst. Evol. Microbiol. 65(10), 3235-3240. Doi: 10.1099/ijsem.0.000400

Kurze, S., H. Bahl, R. Dahl, and G. Berg. 2001. Biological control of fungal strawberry diseases by Serratia plymuthica HRO-C48. Plant Dis. 85(5), 529-534. Doi: 10.1094/PDIS.2001.85.5.529

Lagier, J.C., F. Armougom, M. Million, P. Hugon, I. Pagnier, C. Robert, F. Bittar, G. Fournous, G. Gimenez, M. Maraninchi, J.-F. Trape, E.V. Koonin, B. La Scola, and D. Raoult. 2012. Microbial culturomics: Paradigm shift in the human gut microbiome study. Clin. Microbiol. Infect. 18(12), 1185-1193. Doi: 10.1111/1469-0691.12023

López, J.R., A.L. Diéguez, A. Doce, E. de la Roca, R. de la Herran, J.I. Navas, A.E. Toranzo, and J.L. Romalde. 2012. Pseudomonas baetica sp. nov., a fish pathogen isolated from wedge sole, Dicologlossa cuneata (Moreau). Int. J. Syst. Evol. Microb. 62(4), 874-882. Doi: 10.1099/ijs.0.030601-0

Lorito, M., S.L. Wood, M. D’Ambrosio, G.E. Harman, C.K. Hayes, C.P. Kubicek, and F. Scala. 1996. Synergistic interaction between cell wall degrading enzymes and membrane affecting compounds. Mol. Plant Microbe Interact. 9(3), 206-213. Doi: 10.1094/MPMI-9-0206

Lucy, M., E. Reed, and B.R. Glick. 2004. Applications of free living plant growth-promoting rhizobacteria. Antonie van Leeuwenhoek 86(1), 1-25. Doi: 10.1023/B:ANTO. 0000024903.10757.6e

Luongo, L., M. Galli, L. Corazza, E. Meekes, L. De Haas, C.L. Van Der Plas, and J. Köhl. 2005. Potential of fungal antagonists for biocontrol of Fusarium spp. in wheat and maize through competition in crop debris. Biocontrol Sci. Techn. 15(3), 229-242. Doi: 10.1080/09583150400016852

Marinho, A.M.R., E. Rodrigues-Filho, M.D.L.R. Moitinho, and L.S. Santos. 2005. Biologically active polyketides produced by Penicillium janthinellum isolated as an 
endophytic fungus from fruits of Melia azedarach. J. Braz. Chem. Soc. 16(2), 280-283. Doi: 10.1590/ s0103-50532005000200023

Martínez, S.A. and J. Dussán. 2018. Lysinibacillus sphaericus plant growth promoter bacteria and lead phytoremediation enhancer with Canavalia ensiformis. Environ. Prog. Sustain. Energy 37(1), 276-282. Doi: 10.1002/ ep.12668

Martínez-Medina, A., M. Del Mar Alguacil, J.A. Pascual, and S.C.M. Van Wees. 2014. Phytohormone profiles induced by Trichoderma isolates correspond with their biocontrol and plant growth-promoting activity on melon plants. J. Chem. Ecol. 40(7), 804-815. Doi: 10.1007/s10886-014-0478-1

Mayorga-Cubillos, F., J. Arguelles, E. Rodriguez, C. Almario, C. Ariza, and L. Barrero. 2019. Yield and physicochemical quality of Physalis peruviana L. fruit related to the resistance response against Fusarium oxysporum f. sp. physali. Agron. Colomb. 37(2), 120-128. Doi: 10.15446/agron.colomb.v37n2.77550

McGovern, R.J. 2015. Management of tomato diseases caused by Fusarium oxysporum. Crop Prot. 73, 78-92. Doi: 10.1016/j.cropro.2015.02.021

Melnick, R.L., C. Suárez, B.A. Bailey, and P.A. Backman. 2011. Isolation of endophytic endospore-forming bacteria from Theobroma cacao as potential biological control agents of cacao diseases. Biol. Control 57(3), 236-245. Doi: 10.1016/j.biocontrol.2011.03.005

Michielse, C.B. and M. Rep. 2009. Pathogen profile update: Fusarium oxysporum. Mol. Plant Pathol. 10(3), 311-324. Doi: 10.1111/j.1364-3703.2009.00538.x

Moreno, C.A., F. Castillo, A. González, D. Bernal, Y. Jaimes, M. Chaparro, C. González, F. Rodriguez, S. Restrepo, and A.M. Cotes. 2009. Biological and molecular characterization of the response of tomato plants treated with Trichoderma koningiopsis. Physiol. Mol. Plant Pathol. 74(2), 111-120. Doi: 10.1016/j.pmpp.2009.10.001

Moreno, C.A., J. Kloepper, M. Ongena, and A.M. Cotes. 2014. Biotic factors involved in biological control activity of Bacillus amyloliquefaciens (Bs006) against Fusarium oxysporum in cape gooseberry (Physalis peruviana). pp. 129-136. In: Pertot, I., D.F. Jensen, M. Hökeberg, M. Karlsson, I. Sundh, and Y. Elad (eds.). Proc. XIII Meeting Biocontrol of Plant Diseases: From the Field to the Laboratory and Back Again. IOBC-WPRS Bull. 115. Zürich Switzerland.

Moreno-Limón, S., L.N. González-Solís, S.M. Salcedo-Martínez, M.L. Cárdenas-Avila, and A. Perales-Ramírez. 2011. Efecto antifúngico de extractos de gobernadora (Larrea tridentata L.) sobre la inhibición in vitro de Aspergillus flavus y Penicillium sp. Polibotánica 32, 193-205.

NRCS, National Resources Conservation Service. 2020. Physalis peruviana L.: Peruvian groundcherry. In:
United States Department of Agriculture USDA, https://plants.sc.egov.usda.gov/core/profile?symbol=PHPE4; consulted: November, 2020.

Nicoletti, R., A. Carella, and E. Cozzolino. 2008. Investigation on fungal antagonists of root rot agents from the rhizosphere of white lupin (Lupinus albus). Dyn. Soil Dyn. Plant 2(1), 69-72.

Opelt, K., V. Chobot, F. Hadacek, S. Schönmann, L. Eberl, and G. Berg. 2007. Investigations of the structure and function of bacterial communities associated with Sphagnum mosses. Environ. Microbiol. 9(11), 27952809. Doi: 10.1111/j.1462-2920.2007.01391.x

Osburn, R.M., J.L. Milner, E.S. Oplinger, R.S. Smith, and J. Handelsman. 1995. Effect of Bacillus cereus UW85 on the yield of soybean at two field sites in Wisconsin. Plant Dis. 79(6), 551-556. Doi: 10.1094/PD-79-0551

Ownley, B.H., M.R. Griffin, W.E. Klingeman, K.D. Gwinn, J.K. Moulton, and R.M. Pereira. 2008. Beauveria bassiana: Endophytic colonization and plant disease control. J. Invertebr. Pathol. 98(3), 267-270. Doi: 10.1016/j. jip.2008.01.010

Palma-Guerrero, J., H.B. Jansson, J. Salinas, and L.V. Lopez-Llorca. 2008. Effect of chitosan on hyphal growth and spore germination of plant pathogenic and biocontrol fungi. J. Appl. Microbiol. 104(2), 541-553. Doi: 10.1111/j.1365-2672.2007.03567.x

Pieterse, C.M.J., C. Zamioudis, R.L. Berendsen, D.M. Weller, S.C.M. Van Wees, and P.A.H.M. Bakker. 2014. Induced systemic resistance by beneficial microbes. Annu. Rev. Phytopathol. 52, 347-375. Doi: 10.1146/ annurev-phyto-082712-102340

Ploper, L.D., P.A. Backman, C. Stevens, V.A. Khan, and R. Rodriguez-Kábana. 1992. Effects of soil mulch, row cover, and biological and chemical foliar treatments on early blight of tomato. Biol. Cult. Test. 7, 38.

Prescott, J.F. 1991. Rhodococcus equi: An animal and human pathogen. Clin. Microbiol. Rev. 4(1), 20-34. Doi: 10.1128/CMR.4.1.20

Raaijmakers, J.M. and D.M. Weller. 1998. Natural plant protection by 2,4-diacetylphloroglucinol-producing Pseudomonas spp. in Take-all decline soils. Mol. Plant-Microb. Interact. 11(2), 144-152. Doi: 10.1094/ MPMI.1998.11.2.144

Rai, J.N. and V.C. Saxena. 1975. Sclerotial mycoflora and its role in natural biological control of 'white-rot' disease. Plant Soil 43(1), 509-513. Doi: 10.1007/BF01928513

Rashid, S., T.C. Charles, and B.R. Glick. 2012. Isolation and characterization of new plant growth-promoting bacterial endophytes. Appl. Soil Ecol. 61, 217-224. Doi: 10.1016/j.apsoil.2011.09.011

Refai, M., H.A. El-Yazid, and W. Tawakkol. 2015. Monograph on the genus Penicillium. A guide for historical, classification and identification of penicilli, their industrial applications and detrimental effects. Cairo University, Cairo. 
Rete, A. 2011. Caracterización molecular de Streptomyces spp. asociadas a la sarna común y evaluación in vitro de antagonistas nativos de la rizosfera de papa en Sinaloa. MSc thesis. Instituto Politécnico Nacional, Guasave, Mexico.

Rickerts, V., A. Böhme, A. Viertel, G. Behrendt, V. Jacobi, K. Tintelnot, and G. Just-Nübling. 2000. Cluster of pulmonary infections caused by Cunninghamella bertholletiae in immunocompromised patients. Clin. Infect. Dis. 31(4), 910-913. Doi: 10.1086/318144

Rodriguez, E. 2010. Aislamiento y caracterización de cepas de Fusarium oxysporum en uchuva (Physalis peruviana) y evaluación de la patogenicidad en invernadero. Undergraduate thesis. Universidad de Cundinamaca, Fusagasuga, Colombia.

Rodríguez, E.A. 2013. Caracterización de aislamientos de Fusarium spp. obtenidos de zonas productoras de uchuva (Physalis peruviana) en Cundinamarca y Boyacá. MSc tesis. Facultad de Agronomía, Universidad Nacional de Colombia. Bogota.

Rodríguez, P., A. Cerda, X. Font, A. Sánchez, and A. Artola. 2019. Valorisation of biowaste digestate through solid state fermentation to produce biopesticides from Bacillus thuringiensis. Waste Manage. 93, 63-71. Doi: 10.1016/j.wasman.2019.05.026

Rokhbakhsh-Zamin, F., D. Sachdev, N. Kazemi-Pour, A. Engineer, K.R. Pardesi, S. Zinjarde, P.K. Dhakephalkar, and B.A. Chopade. 2011. Characterization of plant-growth-promoting traits of Acinetobacter species isolated from rhizosphere of Pennisetum glaucum. J. Microbiol. Biotechnol. 21(6), 556-566. Doi: 10.4014/ jmb.1012.12006

Sahebani, N. and N. Hadavi. 2008. Biological control of the root-knot nematode Meloidogyne javanica by Trichoderma harzianum. Soil Biol. Biochem. 40(8), 2016-2020. Doi: 10.1016/j.soilbio.2008.03.011

Sandoval-Denis, M., J. Guarro, J.F. Cano-Lira, D.A. Sutton, N.P. Wiederhold, G.S. de Hoog, S.P. Abbott, C. Decock, L. Sigler, and J. Gené. 2016. Phylogeny and taxonomic revision of Microascaceae with emphasis on synnematous fungi. Stud. Mycol. 83, 193-233. Doi: 10.1016/j.simyco.2016.07.002

Schirmböck, M., M. Lorito, Y.L. Wang, C.K. Hayes, I. Arisan-Atac, F. Scala, G.E. Harman, and C.P. Kubicek. 1994. Parallel formation and synergism of hydrolytic enzymes and peptaibol antibiotics, molecular mechanisms involved in the antagonistic action of Trichoderma harzianum against phytopathogenic fungi. Appl. Environ. Microbiol. 60(12), 4364-4370. Doi: 10.1128/ aem.60.12.4364-4370.1994

Shishido, M., C. Miwa, T. Usami, Y. Amemiya, and K.B. Johnson. 2005. Biological control efficiency of Fusarium wilt of tomato by nonpathogenic Fusarium oxysporum Fo-B2 in different environments. Phytopathology 95(9), 1072-1080. Doi: 10.1094/PHYTO-95-1072
Shoda, M. 2000. Bacterial control of plant diseases. J. Biosci. Bioeng. 89(6), 515-521. Doi: 10.1016/ S1389-1723(00)80049-3

Siegel-Hertz, K., V. Edel-Hermann, E. Chapelle, S. Terrat, J.M. Raaijmakers, and C. Steinberg. 2018. Comparative microbiome analysis of a Fusarium wilt suppressive soil and a Fusarium wilt conducive soil from the Châteaurenard region. Front. Microbiol. 9, 568. Doi: 10.3389/fmicb.2018.00568

Singh, R.K., D.P. Kumar, P. Singh, M.K. Solanki, S. Srivastava, P.L. Kashyap, S. Kumar, A.K. Srivastava, P.K. Singhal, and D.K. Arora. 2014. Multifarious plant growth promoting characteristics of chickpea rhizosphere associated Bacilli help to suppress soil-borne pathogens. Plant Growth Regulation, 73(1), 91-101. Doi: 10.1007/ s10725-013-9870-z

Singh, N.P., R.K. Singh, V.S. Meena, and R.K. Meena. 2015. Can we use maize (Zea mays) rhizobacteria as plant growth promoter? Vegetos 28(1), 86-99. Doi: 10.5958/2229-4473.2015.00012.9

Smith, A. 2012. Reconocimiento de las enfermedades y plagas en el cultivo de uchuva. pp. 9-12. In: Días, A. (ed.). Avances en el manejo y control de Fusarium oxysporum en el cultivo de uchuva (Physalis peruviana). Corpoica, Bogota, DC.

Sobita, S. and A. Anamika. 2011. Agro-based waste products as a substrate for mass production of Trichoderma spp. J. Agric. Sci. 3(4), 168-171. 10.5539/jas.v3n4p168

Spencer, R.C. 2003. Bacillus anthracis. J. Clin. Pathol. 56(3), 182-187. Doi: 10.1136/jcp.56.3.182

Szaniszlo, P.J. and J.L. Harris (eds.). 1985. Fungal dimorphism: With emphasis on fungi pathogenic for humans. Springer, Boston, MA. Doi: 10.1007/978-1-4684-4982-2

Tena, D., C. Fernández, and M.R. Lago. 2015. Alcaligenes faecalis: An unusual cause of skin and soft tissue infection. Jap. J. Infect. Dis. 68(2), 128-130. Doi: 10.7883/ yoken.JJID.2014.164

Toju, H., A.S. Tanabe, S. Yamamoto, and H. Sato. 2012. High-coverage ITS primers for the DNA-based identification of Ascomycetes and Basidiomycetes in environmental samples. PLoS ONE 7(7), e40863. Doi: 10.1371/journal.pone.0040863

Toloza-Moreno, D.L., L.M. Lizarazo-Forero, and D. Uribe-Vélez. 2020. Antagonist capacity of bacteria isolated from cape gooseberry cultures (Physalis peruviana L.) for biological control of Fusarium oxysporum. Trop. Plant Pathol. 45(1), 1-12. Doi: 10.1007/ s40858-019-00313-z

Urrea, R., L. Cabezas, R. Sierra, M. Cárdenas, S. Restrepo, and P. Jiménez. 2011. Selection of antagonistic bacteria isolated from the Physalis peruviana rhizosphere against Fusarium oxysporum. J. Appl. Microbiol. 111(3), 707-716. Doi: 10.1111/j.1365-2672.2011.05092.x 
Velivelli, S.L.S., P. Kromann, P. Lojan, M. Rojas, J. Franco, J.P. Suarez, and B.D. Prestwich. 2015. Identification of mVOCs from andean rhizobacteria and field evaluation of bacterial and mycorrhizal inoculants on growth of potato in its center of origin. Microbiol. Ecol. 69(3), 652-667. Doi: 10.1007/s00248-014-0514-2

Verma, P.S. and C.C. Allison. 1970. Possible modification of susceptibility of tomato to Fusarium wilt by a Chaetomium sp. Phytopathology 60, 1318.

Villarreal-Navarrete, A., G. Fischer, L.M. Melgarejo, G. Correa, and L. Hoyos-Carvajal. 2017. Growth response of the cape gooseberry (Physalis peruviana L.) to waterlogging stress and Fusarium oxysporum infection. Acta Hortic. 1178, 161-168. Doi: 10.17660/ ActaHortic.2017.1178.28

Von Der Weid, I., D.S. Alviano, A.L.S. Santos, R.M.A. Soares, C.S. Alviano, and L. Seldin. 2003. Antimicrobial activity of Paenibacillus peoriae strain NRRL BD-62 against a broad spectrum of phytopathogenic bacteria and fungi. J. Appl. Microbiol. 95(5), 1143-1151. Doi: 10.1046/j.1365-2672.2003.02097.x

Xu, L., S. Ravnskov, J. Larsen, R.H. Nilsson, and M. Nicolaisen. 2012. Soil fungal community structure along a soil health gradient in pea fields examined using deep amplicon sequencing. Soil Biol. Biochem. 46, 26-32. Doi: 10.1016/j.soilbio.2011.11.010

Zacky, F.A. and A.S.Y. Ting. 2013. Investigating the bioactivity of cells and cell-free extracts of Streptomyces griseus towards Fusarium oxysporum f. sp. cubense race 4. Biol. Control 66(3), 204-208. Doi: 10.1016/j. biocontrol.2013.06.001

Zahid, M., M. Kaleem Abbasi, S. Hameed, and N. Rahim. 2015. Isolation and identification of indigenous plant growth promoting rhizobacteria from Himalayan region of Kashmir and their effect on improving growth and nutrient contents of maize (Zea mays L.). Front. Microbiol. 6, 207. Doi: 10.3389/fmicb.2015.00207

Zhang, X., P.R. Harvey, B.E. Stummer, R.A. Warren, G. Zhang, K. Guo, J. Li, and H. Yang. 2015. Antibiosis functions during interactions of Trichoderma afroharzianum and Trichoderma gamsii with plant pathogenic Rhizoctonia and Pythium. Funct. Integr. Genomics 15, 599-610. Doi: 10.1007/s10142-015-0456-x

Zhao, S., D. Liu, N. Ling, F. Chen, W. Fang, and O. Shen. 2014. Bio-organic fertilizer application significantly reduces the Fusarium oxysporum population and alters the composition of fungi communities of watermelon Fusarium wilt rhizosphere soil. Biol. Fertil. Soils 50(5), 765-774. Doi: 10.1007/s00374-014-0898-7 